\title{
Incidence of Listeria spp. in Dairy Cows Feed and Raw Milk in Latvia
}

\author{
I. H. Konosonoka, A. Jemeljanovs, B. Osmane, D. Ikauniece, and G. Gulbe
}

Scientific Institute of Biotechnology and Veterinary Medicine (SIGRA), Latvia University of Agriculture, Instituta street No. 1, 2150 Sigulda, Latvia

Correspondence should be addressed to I. H. Konosonoka, biolab.sigra@lis.lv

Received 24 November 2011; Accepted 2 January 2012

Academic Editor: A. Unver

Copyright ( 92012 I. H. Konosonoka et al. This is an open access article distributed under the Creative Commons Attribution License, which permits unrestricted use, distribution, and reproduction in any medium, provided the original work is properly cited.

Feed is a risk factor for poisoning the farm environment thus also fresh milk with pathogenic microorganisms of Listeria genus species. Listeria ivanovii, Listeria innocua, and Listeria seeligeri were isolated from 9.2\%, but Listeria monocytogenes from $20.0 \%$ of feed samples. Most often different fodders (9.3\%) and silage (4.7\%) were contaminated with Listeria monocytogenes. Listeria genus species were isolated more often from feed prepared and used in organic dairy farm than from that used in conventional dairy farm, correspondingly $44.4 \%$ and $18.3 \%$. No Listeria monocytogenes was found in bulk milk samples of organic dairy farm.

\section{Introduction}

Dairy farming is the leading sector of the Latvia agriculture. We had 7040 dairy herds with 121945 cows in Latvia at the 2010 . Output of milk is $23 \%$, what is the greatest from all agricultural products. Milk processing has always been an important part of Latvia's national economy. Production level of milk products has been increased from 93.9 million LVL at 2002 to 218.2 million LVL at 2008 [1]. Milk and milk products are a traditional part of the Latvian diets. Enhanced nutrition qualities, taste, and health benefits have all been advocated as reasons for increase interest in raw milk consumption. There are 29 states in Europe, int. al. Latvia, which allow the sale of raw milk [2]. Unfortunately, milk is a good source of nutrients and edible energy not only for humans but also for numerous microorganisms, which thus can grow in milk. These microorganisms are primarily bacteria, but some moulds and yeasts can also grow in milk. The presence of several species of microorganisms in raw milk is undesirable, either because the organisms can be pathogenic, or because their growth results in undesirable transformations in the milk $[2,3]$. Bacterial food poisoning is an illness caused by the consumption of food int. al. contaminated with bacteria or bacterial toxins. It is known that bacterial toxins may act as very danger food poisoning substances [4].

The often listed pathogens in raw milk are Staphylococcus aureus, Escherichia coli, Salmonella spp., Shigella spp., Yersinia enterocolitica, Aeromonas hydrophila, Brucella abortus, Campylobacter jejuni, Bacillus cereus, and Listeria monocytogenes (L. monocytogenes), among them $[3,5,6]$.

There are six species in the genus Listeria-L. monocytogenes, L. ivanovii, L. innocua, L. seeligeri, L. Welshimeri, and L. grayi. Results of genomic analysis suggest that these species fall into three main groups. The first contains $L$. monocytogenes, L. Innocua, and L. welshimeri, the second group L. ivanovii and L. seeligeri, and the third L. grayi [7]. Only two, L. monocytogenes and L. ivanovii, are pathogenic for humans and animals $[8,9]$. The cellular behaviour of L. ivanovii is quite similar to that of L. monocytogenes, and the virulence gene cluster of $L$. monocytogenes is present in the other pathogenic species L. ivanovii [10]. Investigations of Chakraborty et al. [11] reveal that the ability to grow in the host cytoplasm cause vasodilatorstimulated phosphoprotein, which is characteristic both for L. monocytogenes and L. ivanovii. L. monocytogenes is a high adaptable environmental bacterium capable of existing both as animal pathogen and plant saprophyte with powerful 
array of regulated virulence factors [12]. At the same time it is potentially lethal foodborne pathogen commonly found in dairy cows' environment - in cow feces, silage, soil, water, and so forth [13]. It is proved that L. monocytogenes grows into biofilms attached to the surfaces in food-processing plants $[14,15]$ and milking systems in dairy farms. The common treatment of surfaces is not effective to eliminate this dangerous foodborne pathogen, and it easily can pass into raw milk. L. monocytogenes can cause a rare but serious disease called listeriosis, especially among pregnant women, the elderly, or individuals with a weakened immune system. L. monocytogenes is more likely to cause death than other bacteria that cause food poisoning. 20 to $30 \%$ of foodborne listeriosis infections in high-risk individuals may be fatal [16].

The presence of pathogens depends on ingestion of contaminated feed followed by amplification in bovine hosts and fecal dissemination in the farm environment. The final outcome of this cycle is a constantly maintained reservoir of foodborne pathogens that can reach humans by direct contact, ingestion of raw contaminated milk or cheese, or contamination during the processing of milk products [17].

Raw milk is offered for sale in every market place in Latvia. Therefore it is essential to gather information about microbial risk factors and hazards associated with raw milk production. Risk assessment and microbial monitoring will continue to play important role in ensuring food safety [4]. Critical control point management programmes created for individual milk production farms based upon risk analysis, total quality management and hazard analysis, and critical control point principles are essential for obtaining safe and healthy raw milk for consumers and for processing.

The objective of this study was to clarify incidence of bacteria from the genus Listeria int. al. foodborne pathogen L. monocytogenes in the feed and raw milk from one organic and three conventional dairy farms in Latvia.

\section{Materials and Methods}

2.1. Sampling. The research was carried out from June 2008 to May 2010. In total, 130 feed samples and 244 bulk tank milk samples from organic farm "Grantskalni" and three conventional farms "Palsa," "Lacplesa piens," and "Robeznieki" were analyzed. Feed and milk samples were collected randomly in all seasons of year.

2.2. Isolation of Listeria spp. L. monocytogenes from feed and milk samples were isolated in accordance with international standard LVS EN ISO 11290-1+A1 "Microbiology of food and animal feeding stuffs-Horizontal method for detection and enumeration of Listeria monocytogenes-Part 1: detection method". Presumptive L. monocytogenes isolates were purified and confirmed by the Fourier transform infrared spectroscopy (FT-IR) technique.

Identification of Listeria Species Using FT-IR. Sample preparation and measurement of FT-IR spectra were performed according to manufacturer's instructions using an infrared spectrometer Tensor 27 and software OPUS version 6.5 (Bruker optic GmbH, Germany). The bacterial strains were subcultured on tryptone soya agar (TSA, OXOID) by incubating the plates at $37^{\circ} \mathrm{C}$ for $24 \mathrm{~h}$. Bacteria inoculum was transferred from the TSA preculture onto the surface of the TSA plate with a loop and spread with spatula until homogeneity bacterial lawn (one half of the agar plate is enough for each strain). Prepared plates were incubated for $24 \mathrm{~h}$ at $30^{\circ} \mathrm{C}$. After incubation suspensions with 2 full loops of the bacteria scraped from the confluent lawn in $100 \mu \mathrm{L}$ distilled water in the Eppendorf tubes were prepared. Afterwards we homogenized this suspension with a vortex for $10 \mathrm{sec}$., transferred $25 \mu \mathrm{L}$ of the suspension on the microtiter plate, and dried about $45 \mathrm{~min}$. at $42^{\circ} \mathrm{C}$. For the FT-IR absorption measurements we used 32 scans, $6 \mathrm{~cm}^{-1}$ resolution, 24 phase resolution, and repeated background position measurements between 4,000 and $500 \mathrm{~cm}^{-1}$. Identification of bacteria was based on Bruker's spectral library of Listeria species which includes reference strains of L. monocytogenes, L. innocua, $L$. ivanovii, L. Welshimeri, and L. seeligeri.

2.3. Statistical Analysis. Listeria spp. and L. monocytogenes prevalence were analyzed with Statistical Package for Social Sciences 17.0 for Windows (SPSS Inc., Chicago, IL, USA).

\section{Results and Discussion}

The bacteria of Listeria species were detected in feed samples $(n=130)$ in 38 cases or $29.2 \%$. In $12(9.2 \%)$ these were $L$. innocua, L. Ivanovii, and L. seeligeri, but in 26 cases $(20.0 \%)$ L. monocytogenes.

Bacteria of Listeria genus can be widely found in nature-in soil, on plants, in waters, on animal hair and birds' bodies, and so forth. Thus they can easily get into the feed for dairy cows. Literature sources show that both L. monocytogenes and L. ivanovii cause animal and human infections. L. ivanovii shares certain characteristics with $L$. monocytogenes (e.g., hemolysis) and is occasionally associated with abortion in ruminants [9]. Therefore incidence of these two species in animal feed is a risk factor for presence of Listeria in the farm environment, cow infections, their presence in milk and thus also in human body causing infections.

Animal and human pathogen L. monocytogenes was isolated from 26 feed samples (20.0\%). Milk plays important role in L. monocytogenes epidemiology [18, 19]; therefore it must be kept in mind that these dangerous bacteria are brought in the farm environment by contaminated feed and thus also on cow hair, udder, and teat skin and then also in milk. L. monocytogenes is known as cow mastitis [20], conjunctivitis, and other disease-causing pathogen microorganisms. It has been proved that Listeria strains isolated from infections have been found also in farm environment-in feces and silage which means that $L$. monocytogenes strains found in nature are virulent [21].

Incidence of Listeria spp. and L. monocytogenes in different type of feed has been summarized in Table 1.

As it can be seen, the data summarized in Table 1 show that none of 14 different grass samples contains bacteria of 
TABLE 1: Incidence of Listeria species in feed of dairy cows.

\begin{tabular}{lcc}
\hline Type of feed & Listeria spp. $n(\%)$ & L. monocytogenes $n(\%)$ \\
\hline Grass $(n=14)$ & Not detected & Not detected \\
Silage $(n=48)$ & $4(3.1)$ & $6(4.7)$ \\
Haylage $(n=16)$ & $2(1.5)$ & $2(1.5)$ \\
Hay $(n=10)$ & Not detected & $2(1.5)$ \\
Feed concentrates $(n=32)$ & Not detected & $12(9.3)$ \\
Mixed fodder prepared in the farm $(n=4)$ & $2(1.5)$ & $2(1.5)$ \\
Straw $(n=6)$ & $4(3.1)$ & $2(1.5)$ \\
Total $(n=130)$ & $12(9.2)$ & $26(20.0)$ \\
\hline
\end{tabular}

TABLE 2: Share of Listeria spp. and Listeria monocytogenes in feed depending of type of farm and season.

\begin{tabular}{|c|c|c|c|c|c|c|}
\hline \multirow{2}{*}{ Season } & \multicolumn{3}{|c|}{ Organic farming } & \multicolumn{3}{|c|}{ Conventional farming } \\
\hline & Number of samples & Listeria spp., $n(\%)$ & L. monocytogenes, $n(\%)$ & Number of samples & Listeria spp., $n(\%)$ & L. monocytogenes, $n(\%)$ \\
\hline Winter & 19 & $4(7.4)$ & $10(18.5)$ & 30 & $2(2.6)$ & $8(10.5)$ \\
\hline Spring & 14 & $2(3.7)$ & $2(3.7)$ & 14 & 0 & 0 \\
\hline Summer & 6 & 0 & 0 & 14 & 0 & 0 \\
\hline Autumn & 15 & $2(3.7)$ & $4(7.4)$ & 18 & $2(2.6)$ & $2(2.6)$ \\
\hline Total & 54 & $8(14.8)$ & $16(29.6)$ & 76 & $4(5.2)$ & $10(13.1)$ \\
\hline
\end{tabular}

Listeria species. Thus, grass has not been in contact with dung, wild animal feces, which can cause the presence of Listeria in the soil and on plants.

Silage is considered as the main source of L. monocytogenes and other Listeria genus bacteria in farm environment [22]. However, neither silage $(n=48)$ nor haylage $(n=16)$ were highly contaminated in our study; it ranges from 1.5 to $4.7 \%$ (Table 1 ).

Dry food products were contaminated with $L$. monocytogenes: feed mixture prepared in the farm-1.5\%, different fodder products (different corns, rape cakes, etc.)-9.3\%, straw $-1.5 \%$, and hay- $1.5 \%$ of all tested samples $(n=$ 130) (Table 1). The tested straw and hay were stored at the field during winter therefore exposed to long-term impact of environment. Birds and wild animals are the main carriers of Listeria spp. in nature, so they also could contaminate straw and hay used in the farm. Hay used as fodder might have been contaminated on the field by bird and animal feces. Listerias are gram-positive bacteria with different structure and chemical content of its cell wall and thus more resistant than gram-negative ones. Listeria cell wall protects the inner content of the cell against impact of external mechanical and osmotic force, insufficient humidity and $\mathrm{pH}$ level, and other damaging growing and reproduction factors. The cell wall of gram-positive bacteria consists of peptidoglycan which is associated with teichoic acids and lipoteichoic acids in complex multilayer structure, while the cell wall of gramnegative bacteria consists of one peptidoglycan layer which is covered with a membrane $[5,23]$. Thus, the cell wall of gram-positive bacteria, including Listeria is tenfold thicker than the cell wall of gram-negative bacteria, and they are much viable in external environment, as well as considerably resistant to disinfectants use for cow teat treatment before milking. Listeria spp. can multiply in diverse environmental conditions. It is able to grow at temperatures from $+1^{\circ} \mathrm{C}$, they can be considered as psychrophilic microorganisms [24] capable of surviving, growing, and multiplying in feed also in autumn and winter, when straw, hay roll, and hay are on the field or under open sheds.

Table 2 shows summarized obtained data on incidence of Listeria spp. and L. monocytogenes in organic and conventional farms and feed used in different seasons.

The data summarized in Table 2 show that feed was free of Listeria during summer in both organic and conventional farms. Our studies are proved by literature data on the fact that Listeria spp. is most likely isolated from feedstuff in winter and autumn than it is in summer $[25,26]$. The obtained results show that both Listeria spp. and $L$. monocytogenes are found more often in feed prepared in organic farm (correspondingly $14.8 \%$ and $29.6 \%$ ) than in feed used in conventional farms (correspondingly $5.2 \%$ and $13.1 \%)$. Results are logical as, according to the legislative acts of the European Union, organic farms should use as less chemical substances as possible; for example, ferments, yeast, and bacteria should be used as silage additives instead of chemical preservatives thus limiting multiplication of pathogenic bacteria.

Although different feed samples contained L. monocytogenes, no such bacteria were found in samples of bulk milk from organic farm $(n=33)$, but in samples of bulk milk from conventional farm L. monocytogenes was found three times or in $1.4 \%$ of all cases $(n=211)$. Similar results were obtained in studies of other scientists. Fernandez et al. [27] has isolated L. monocytogenes from 3.0\% $(n=140)$, Jayarao and Henning [28] from 3.8\%, but Vilar et al. [29] from 6.1\% of bulk milk samples.

The obtained results show that accurate observing of hygiene standards concerning treatment of cows' udder and 
teats, as well as proper washing and cleaning process of milking system pipe lines and cooling tanks, protects the milk against bacteria.

\section{Conclusions}

Different type of feed is a risk factor for poisoning the farm environment thus also poisoning fresh milk with pathogenic microorganisms of Listeria genus species in both organic and conventional farms. Listeria ivanovii, Listeria innocua, and Listeria seeligeri were isolated from 9.2\%, but Listeria monocytogenes from $20.0 \%$ of feed samples. Most often different feed concentrates (9.3\%) and silage $(4.7 \%)$ were contaminated with Listeria monocytogenes. Listeria genus species were isolated more often from feed prepared and used in organic dairy farm than from the feed used in conventional dairy farms, correspondingly $44.4 \%$ and $18.3 \%$.

No Listeria monocytogenes were found in bulk milk samples from organic dairy farm $(n=33)$, but they were found three times in samples of conventional dairy farms $(n=211)$.

\section{References}

[1] Ministry of Agriculture Republic of Latvia, 2011, http:// www.icar.org/Documents/Riga_2010/ppt/Nabels-Sneiders.pdf.

[2] S. P. Oliver, K. J. Boor, S. C. Murphy, and S. E. Murinda, "Food safety hazards associated with consumption of raw milk," Foodborne Pathogens and Disease, vol. 6, no. 7, pp. 793806, 2009.

[3] P. Walstra, J. T. M. Wouters, and T. J. Geurts, "Microbiology of milk," in Dairy Science and Technology, pp. 175-203, 2006.

[4] J. Bielecki, "Emerging food pathogens and bacterial toxins," Acta Microbiologica Polonica, vol. 52, supplement, pp. 17-22, 2003.

[5] J. Garbutt, Essentials of Food Microbiology, Hodder Arnold, London, UK, 1997.

[6] A. Blija, "Pārtikas infekcijas, to cēloņi," in Pārtikas un Uztura Kvalitāte un Drošums, pp. 72-85, LU Akadēmiskais Apgāds, Rìga, Latvia, 2007.

[7] T. Hain, S. S. Chatterjee, R. Ghai et al., "Pathogenomics of Listeria spp." International Journal of Medical Microbiology, vol. 297, no. 7-8, pp. 541-557, 2007.

[8] P. S. Mead, L. Slutsker, V. Dietz et al., "Food-related illness and death in the United States," Emerging Infectious Diseases, vol. 5, no. 5, pp. 607-625, 1999.

[9] C. J. Czuprynski, S. Kathariou, and K. Poulsen, "Listeria," in Pathogenesis of Bacterial Infections in Animals, pp. 167-187, Wiley-Blackwell, 4th edition, 2010.

[10] E. Gouin, J. Mengaud, and P. Cossart, "The virulence gene cluster of Listeria monocytogenes is also present in Listeria ivanovii. an animal pathogen, and Listeria seeligeri, a nonpathogenic species," Infection and Immunity, vol. 62, no. 8, pp. 3550-3553, 1994.

[11] T. Chakraborty, F. Ebel, E. Domann et al., "A focal adhesion factor directly linking intracellularly motile Listeria monocytogenes and Listeria ivanovii to the actin-based cytoskeleton of mammalian cells," The EMBO Journal, vol. 14, no. 7, pp. 13141321, 1995.
[12] J. C. Low and W. Donachie, "A review of Listeria monocytogenes and listeriosis," Veterinary Journal, vol. 153, no. 1, pp. 9-29, 1997.

[13] E. Fox, T. O’Mahony, M. Clancy, R. Dempsey, M. O’Brien, and K. Jordan, "Listeria monocytogenes in the Irish dairy farm environment," Journal of Food Protection, vol. 72, no. 7, pp. 1450-1456, 2009.

[14] C. Arizcun, C. Vasseur, and J. C. Labadie, "Effect of several decontamination procedures on Listeria monocytogenes growing in biofilms," Journal of Food Protection, vol. 61, no. 6, pp. 731-734, 1998.

[15] A. J. Roberts and M. Wiedmann, "Pathogen, host and environmental factors contributing to the pathogenesis of listeriosis," Cellular and Molecular Life Sciences, vol. 60, no. 5, pp. 904-918, 2003.

[16] V. Ramaswamy, V. M. Cresence, J. S. Rejitha et al., "Listeriareview of epidemiology and pathogenesis," Journal of Microbiology, Immunology and Infection, vol. 40, no. 1, pp. 4-13, 2007.

[17] S. P. Oliver, B. M. Jayarao, and R. A. Almeida, "Foodborne pathogens in milk and the dairy farm environment: food safety and public health implications," Foodborne Pathogens and Disease, vol. 2, no. 2, pp. 115-129, 2005.

[18] D. C. Edson, S. Empson, and L. D. Massey, "Pathogen detection in food microbiology laboratories: an analysis of qualitative proficiency test data, 1999-2007," Journal of Food Safety, vol. 29, no. 4, pp. 521-530, 2009.

[19] P. Poltronieri, M. D. de Blasi, and O. F. D'Urso, “Detection of Listeria monocytogenes through real-time PCR and biosensor methods," Plant, Soil and Environment, vol. 55, no. 9, pp. 363369, 2009.

[20] A. Bourry and B. Poutrel, "Bovine mastitis caused by Listeria monocytogenes: kinetics of antibody responses in serum and milk after experimental infections," Journal of Dairy Science, vol. 79, no. 12, pp. 2189-2195, 1996.

[21] K. Evans, M. Smith, P. McDonough, and M. Wiedmann, "Eye infections due to Listeria monocytogenes in three cows and one horse," Journal of Veterinary Diagnostic Investigation, vol. 16, no. 5, pp. 464-469, 2004.

[22] M. K. Borucki, C. C. Gay, J. Reynolds et al., "Genetic diversity of Listeria monocytogenes strains from a high-prevalence dairy farm," Applied and Environmental Microbiology, vol. 71, no. 10, pp. 5893-5899, 2005.

[23] L. B. Borisov, Medical Microbiology, Virology, Immunology, Medical News Agenstvo, Moscow, Russia, 2002.

[24] D. R. Fenlon and J. Wilson, "The incidence of Listeria monocytogenes in raw milk from farm bulk tanks in NorthEast Scotland," Journal of Applied Bacteriology, vol. 66, no. 3, pp. 191-196, 1989.

[25] A. A. M. Abou-Eleinin, E. T. Ryser, and C. W. Donnelly, "Incidence and seasonal variation of Listeria species in bulk tank goat's milk," Journal of Food Protection, vol. 63, no. 9, pp. 1208-1213, 2000.

[26] D. R. Fenlon, "Rapid quantitave assesment of the distribution of Listeria in silage implicated in a suspected outbrake of listeriosis in calves," Veterinary Record, vol. 118, pp. 240-242, 1986.

[27] L. B. Fernandez, G. Flores, A. A. Gonzalez, J. Valladeres, P. Castro, and S. Pereira, Hygienic quality in concentrates, milk and grass and maize silages in dairy farms in Galicia, Spain, 2008, http://agris.fao.org/agris-search/search/display.do?f= 2008\%2FES\%2FES0808.xml\%3BES2008001649.

[28] B. M. Jayarao and D. R. Henning, "Prevalence of foodborne pathogens in bulk tank milk," Journal of Dairy Science, vol. 84, no. 10, pp. 2157-2162, 2001. 
[29] M. J. Vilar, E. Yus, M. L. Sanjuán, F. J. Diéguez, and J. L. Rodríguez-Otero, "Prevalence of and risk factors for Listeria species on dairy farms," Journal of Dairy Science, vol. 90, no. 11, pp. 5083-5088, 2007. 

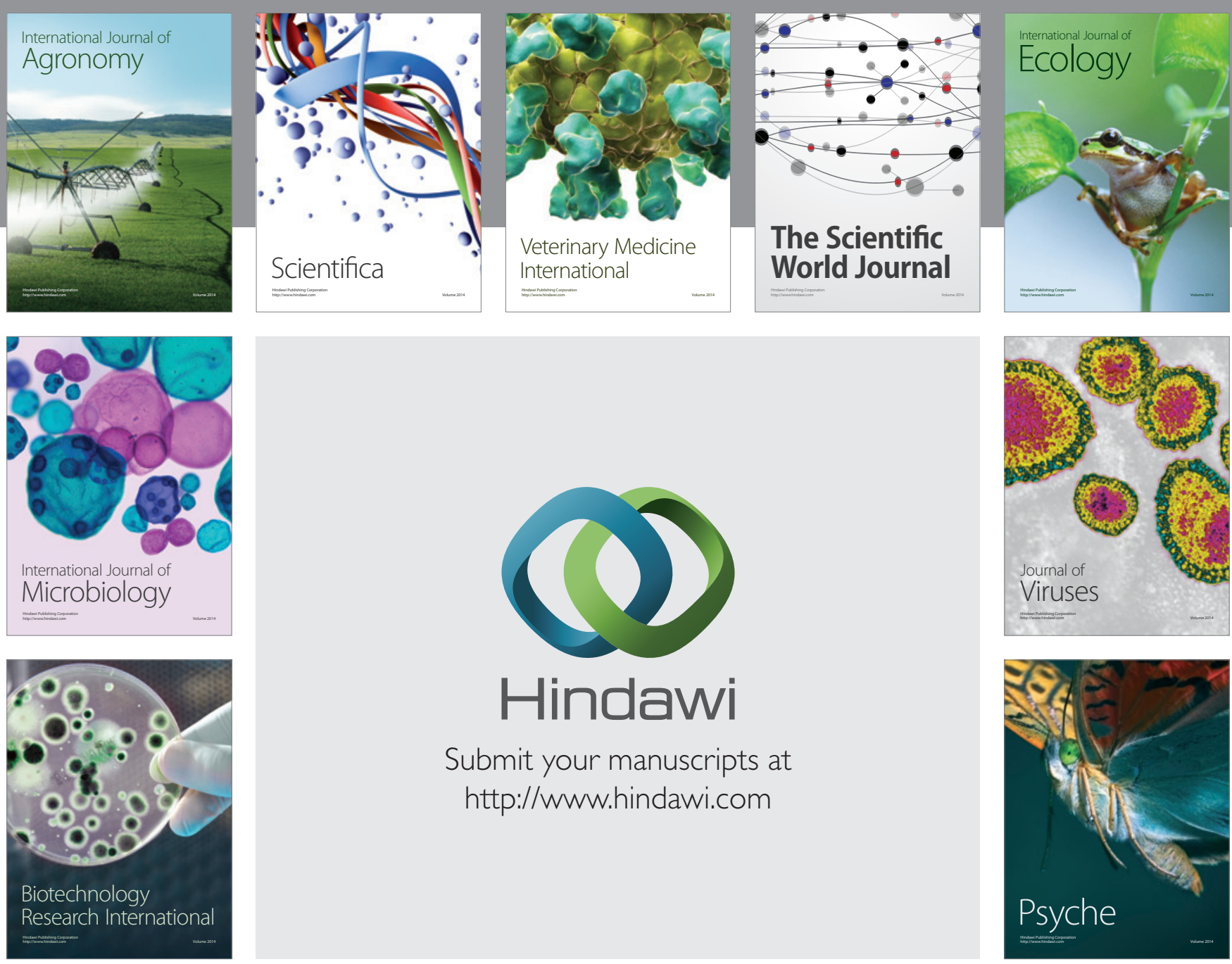

Submit your manuscripts at http://www.hindawi.com
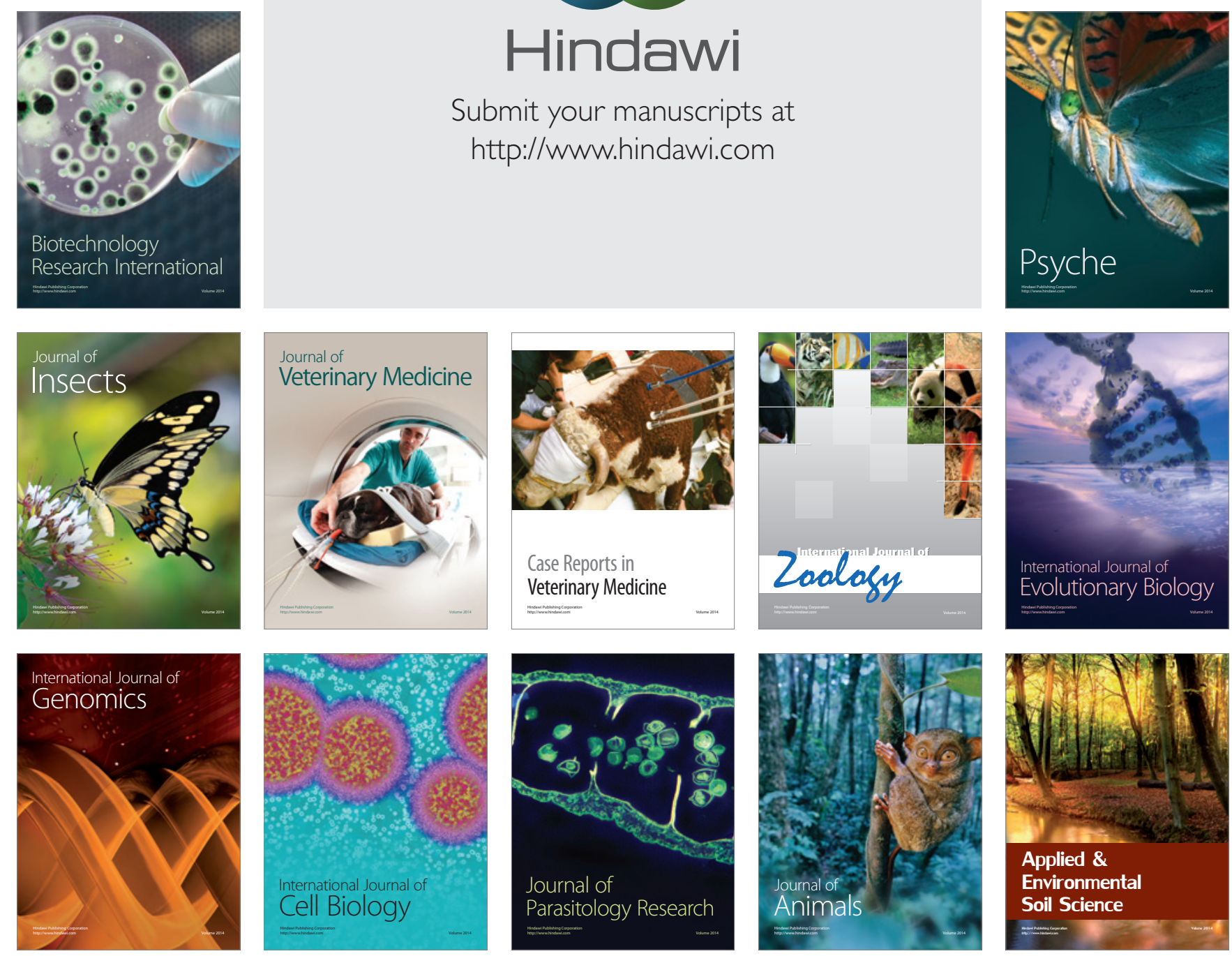